\title{
ANALISIS KEPUASAN PELANGGAN PDAM KOTA DENPASAR DITINJAU DARI ASPEK TEKNIS
}

\author{
Separdi Haja ${ }^{1}$, I N. Norken ${ }^{2}$, dan I Ketut Suputra ${ }^{2}$
}

Abstrak : Perusahaan Daerah Air Minum (PDAM) kota Denpasar merupakan salah satu PDAM yang memiliki predikat sehat dari tahun 2009-2012 berdasarkan hasil penilaian Badan Pendukung Pengembangan Sistem Penyediaan Air Minum (BPPSPAM). Namun pada kenyataannya masih banyak keluhan pelanggan yang terdengar di media cetak maupun elektronik. Dari laporan tahunan PDAM kota Denpasar tahun 2013 tercatat sebanyak 6.738 kasus pengaduan mengenai pelayanan dan 83,38 persen berasal dari aspek teknis. Penelitian ini bertujuan untuk mengetahui tingkat kepuasan pelanggan, indikator yang mempengaruhi kepuasan pelanggan dan indikator apa saja yang harus diperbaiki untuk meningkatkan kepuasan pelanggan dari aspek teknis. Penelitian ini dilakukan di kota Denpasar dengan responden sebanyak 398 orang pelanggan rumah tangga PDAM kota Denpasar. Analisis yang digunakan adalah analisis Importance-Performance dan analisis Gap. Analisis Importance-Performance menghasilkan indikator-indikator yang berpengaruh dan harus diperbaiki untuk meningkatkan kepuasan pelanggan. Sedangkan analisis Gap akan menghasilkan tingkat kepuasan pelanggan PDAM kota Denpasar. Secara umum, Pelanggan merasa belum puas terhadap pelayanan aspek teknis yang diterima. Hal ini terlihat dari nilai Gap sebesar -1,01 dan tingkat kesesuian kinerja dan kepentingan bernilai 0,76 (kurang dari 1). Tingkat kepuasan pelanggan PDAM kota Denpasar untuk aspek pengaduan mengenai perpipaan $(-1,09)$ berada pada tingkat kepuasan rendah $(-1,059 \leq \mathrm{I}<-1,01)$ sedangkan kepuasan untuk aspek kualitas air $(-0,982)$, kontinuitas air $(-$ $0,975)$, kecepatan pemasangan instalasi sambungan baru $(-1,003)$ dan meter air $(-0,973)$ berada pada tingkat kepuasan sedang $(-1,01 \leq \mathrm{I}<-0,961)$. Adapun indikator yang mempengaruhi kepuasan pelanggan adalah kejernihan air, bau air, rasa air, kandungan zat kimia, ketersediaan air pada jam aktifitas kehidupan, kesigapan operator dalam pemasangan intalasi sambungan baru, pembacaan meter air, perbaikan kerusakan meter air, dan kesigapan/kecepatan penanganan pengaduan mengenai perpipaan. Beberapa indikator harus ditingkatkan kinerjanya oleh PDAM kota Denpasar untuk meningkatkan kepuasan pelanggan adalah kejernihan air, bau air, ketersediaan air pada jam aktifitas kehidupan, kesigapan operator dalam pemasangan instalasi sambungan baru, perbaikan kerusakan meter air, dan kesigapan/kecepatan penanganan pengaduan mengenai perpipaan.

Kata kunci $\quad$ : kepuasan pelanggan PDAM, aspek teknis, analisis Importance-Performance, analisis Gap.

\section{ANALYSIS OF PDAM DENPASAR CITY CUSTOMER'S SATISFACTION REVIEWED FROM} TECHNICAL ASPECT

\begin{abstract}
Regency Water Supply Company (PDAM) of Denpasar city is one of the PDAM that have a healthy predicate from 2009-2012 based on the results by the assessment Development Support Agency of Water Supply System (BPPSPAM). But in fact many customer complaints are heard in the newspaper and electronic media. From PDAM of Denpasar city annual report in 2013, there were 6,738 cases of complaints regarding service and 83.38 percent came from the technical aspect. This research aims to determine the level of customer satisfaction, the indicators that affect customer satisfaction and indicators affecting what should be improved to increase customer satisfaction reviewed from technical aspect. This research was conducted in Denpasar city with the 398 respondents who are household customer PDAM of Denpasar. The analysis took based on the ImportancePerformance analysis and Gap analysis. Importance-Performance analysis resulted in indicators of influence and should be improved to increase customer satisfaction. While the Gap analysis showed the level of customer satisfaction PDAM of Denpasar city. The majority of customer were dissatisfied with the service received from technical aspects. Shown from the Gap of -1.01 and suitability level of performance and the importance is worth 0.76 (less than 1). The level of customer satisfaction PDAM Denpasar city for complaints of the piping aspect ($1.09)$ is at a low level satisfaction $(-1,059 \leq \mathrm{I}<-1,01)$, while satisfaction level for the water quality $(-0.982)$, water continuity $(-0.975)$, speed installation of new connections $(-1.003)$ and water meters $(-0.973)$ are at moderate levels of satisfaction(-1,01 $\leq \mathrm{I}<-0,961)$. The indicators that affect customer satisfaction are the clarity of the water, smelly water, flavored water, chemical content, hours of availability of water in the life activity, alertness operators in the installation of new connection, reading the water meter, water meter repair damage, and alertness/speed handling of complaints about the piping. Some performance indicators should be improved by the PDAM of Denpasar city to improve customer satisfaction are the clarity of the water, the smell of the water, the availability of water at life activity, alertness operators in the installation of new connections, water meters repair damage, and alertness/speed handling of complaints about the piping.
\end{abstract}

Keywords : customer PDAM satisfaction, technical aspect, Importance-Performance analysis, Gap analysis.

\footnotetext{
${ }^{1}$ Mahasiswa Program Studi Magister Teknik Sipil, Program Pascasarjana Universitas Udayana.

${ }^{2}$ Staf Pengajar Program Studi Magister Teknik Sipil, Program Pascasarjana Universitas Udayana.
} 


\section{PENDAHULUAN}

\section{LatarBelakang}

Perusahaan Daerah Air Minum atau dikenal dengan PDAM menurut UU No 5 tahun 1962 adalah merupakan suatu kesatuan usaha milik pemerintah daerah yang memberikan jasa pelayanan dan menyelenggarakan kemanfaatan umum dibidang air minum.

Tingkat pertambahan penduduk kota Denpasar yang tinggi menyebabkan kebutuhan masyarakat akan air bersih meningkat. Sehingga PDAM kota Denpasar berupaya untuk mengoptimalkan kinerja untuk memenuhi kebutuhan air bersih masyarakat. Saat ini PDAM kota Denpasar memiliki 21 sumur bor, 3 sumber air permukaan dan membeli air dari PDAM kab. Badung dan PDAM kab. Gianyar.

Menurut evaluasi Badan Pendukung Pengembangan sistem Penyediaan air Minum (BPPSPAM), PDAM kota Denpasar dikategorikan sebagai PDAM sehat dari tahun 2009 hingga 2012. Penilaian tersebut meliputi aspek keuangan, aspek pelayanan, aspek operasional dan aspek sumber daya manusia. Namun pada kenyataannya masih sering terdengar keluhan pelanggan dan berita terkait PDAM kota Denpasar baik melalui media cetak, elektronik dan online. Hasil rekapitulasi pengaduan external PDAM kota Denpasar tahun 2013 tercatat bahwa jumlah pengaduan sepanjang tahun 2013 sebanyak 6.738 kasus dengan 83,38\% diantaranya berasal dari aspek teknis.

Berdasarkan permasalahan dan keluhan pelanggan yang timbul oleh ketidakpuasan tersebut di atas maka diperlukan pengukuran tingkat kepuasan pelanggan dan faktor apa saja yang mempengaruhi kepuasan pelanggan PDAM kota Denpasar ditinjau dari aspek teknis yang mengacu pada aspek operasional keputusan MENDAGRI No 47 tahun 1999 tentang pedoman penilaian kinerja perusahaan daerah air minum (PDAM) dan struktur masalah kinerja teknis PDAM yang dikeluarkan oleh PERPAMSI tahun 2009 yang meliputi: (1) kualitas air distribusi; (2) kontinuitas air; (3) kecepatan pemasangan intalasi sambungan baru; (4) meter air; (5) pengaduan mengenai perpipaan.

\section{Tujuan Penelitian}

Tujuan dari penelitian ini adalah :

1) Untuk mengetahui tingkat kepuasan pelanggan PDAM Kota Denpasar jika ditinjau dari aspek teknis.

2) Indikator dari aspek teknis apa saja yang berpengaruh pada tingkat kepuasan pelanggan PDAM Kota Denpasar.

3) Indikator dari aspek teknis apa saja yang harus diperbaiki PDAM Kota Denpasar untuk memenuhi kepuasan pelanggan.

\section{KAJIAN PUSTAKA}

PDAM atau Perusahaan Daerah Air Minum merupakan salah satu unit usaha milik daerah, yang yang bergerak dalam distribusi air bersih bagi masyarakat umum. PDAM terdapat di setiap provinsi, kabupaten, dan kotamadya di seluruh Indonesia. PDAM merupakan perusahaan daerah sebagai sarana penyedia air bersih yang diawasi dan dimonitor oleh aparataparat eksekutif maupun legislatif daerah (Wikipedia Bahasa Indonesia).

Kepuasan pelanggan merupakan evaluasi pembeli dimana alternatif yang dipilih sekurangkurangnya memberikan hasil (outcome) sama atau melampaui harapan pelanggan, sedangkan ketidakpuasan timbul apabila hasil yang diperoleh tidak memenuhi harapan pelanggan. (Engel, 1990, "Consumer Behavior" dalam Agustina, 2007). Sedangkan Dalam Widyaningrum, 2004. Rangkuti mendefinisikan kepuasan pelanggan sebagai respon pelanggan terhadap ketidaksesuian antara tingkat kepentingan sebelumnya dan kinerja aktual yang dirasakannya setelah pemakaian.

Menurut Gerson dalam Widyaninngrum (2004), ada lima manfaat dari pengukuran mutu dan kepuasan pelanggan, sebagai berikut:

1. Pengukuran menyebabkan orang memiliki rasa berhasil dan berprestasi, yang kemudian diterjemahkan menjadi pelayanan yang prima kepada pelanggan.

2. Pengukuran bisa dijadikan dasar menentukan standar kinerja dan standar prestasi yang harus dicapai, yang akan mengarahkan menuju mutu yang semakin baik dan kepuasan pelanggan yang meningkat.

3. Pengukuran memberikan umpan balik segera kepada pelaksana, terutama bila pelanggan sendiri yang mengukur kinerja pelaksana atau perusahaan yang memberikan pelayanan.

4. Pengukuran memberitahu apa yang harus dilakukan untuk memperbaiki mutu dan kepuasan pelanggan serta bagaimana harus melakukannya.

5. Pengukuran memotivasi orang untuk melakukan dan mencapai tingkat produktivitas yang lebih tinggi.

\section{Penelitian sejenis}

Penelitian sejenis yang pernah dilakukan di Denpasar mengenai kepuasan pelanggan terhadap PDAM Kota Denpasar adalah penelitian Yuliarni dan Riyasa, "Analisis Faktor-faktor yang Mempengaruhi Kepuasan Pelanggan Terhadap Pelayanan PDAM Kota Denpasar" Buletin Studi Ekonomi Volume 12 Nomor 1 tahun 2007. Penelitian ini mengacu pada Penelitian Widyaningrum, 2004 mengenai "Analisis Kualitas Pelayanan Terhadap Kepuasan Pelanggan (Studi Kasus di PDAM Tirta Pakuan Kota Bogor)"

Relevansi penelitian terdahulu dengan penelitian ini adalah untuk memberikan upaya optimal dalam memenuhi tuntutan kualitas pelayanan yang lebih baik terhadap pelanggan PDAM kota Denpasar. Persamaan penelitian ini dengan penelitian sebelumnya adalah sama-sama untuk mengetahui faktor-faktor dan tingkat kepuasan pelanggan PDAM. 
Perbedaan penelitian ini dengan penelitian sebelumnya adalah yang menjadi pokok masalah penelitian ini adalah tingkat kepuasan pelanggan PDAM Kota Denpasar jika ditinjau dari aspek teknis yang mengacu pada aspek operasional keputusan MENDAGRI No 47 tahun 1999 tentang pedoman penilaian kinerja perusahaan daerah air minum (PDAM) dan struktur masalah kinerja teknis PDAM yang dikeluarkan oleh PERPAMSI tahun 2009 yang meliputi: (1) kualitas air distribusi; (2) kontinuitas air; (3) kecepatan pemasangan intalasi sambungan baru; (4) meter air; (5) pengaduan mengenai perpipaan.

\section{METODE PENELITIAN}

\section{Kerangka Konsep Penelitian}

Penelitian tentang kepuasan pelanggan telah banyak dilakukan, terutama pada kepuasan pelanggan Perusahaan Daerah Air Minum (PDAM). Penelitian mengenai kepuasan pelanggan PDAM biasanya terpusat pada sistem kinerja pelayanan, kinerja keuangan dan kinerja manajemen. Meninjau kepuasan pelanggan PDAM dari aspek teknis belum banyak dilakukan hal ini disebabkan belum adanya acuan mengenai konsep kepuasan pelanggan jika ditinjau dari aspek teknis.

Penelitian ini merumuskan beberapa faktor yang digolongkan sebagai aspek teknis dalam kinerja Perusahaan Daerah Air Minum (PDAM). Adapun yang menjadi acuan dalam merumuskan faktor-faktor tersebut adalah:

1. Aspek Operasional, Keputusan Menteri Dalam Negeri nomor 47 tahun 1999 tentang pedoman penilaian kinerja perusahaan daerah air minum Adapun yang termasuk dalam aspek operasional adalah (1) cakupan pelayanan; (2) kualitas air distribusi; (3) kontinuitas air; (4) produktivitas pemanfaatan instalasi produksi; (5) tingkat kehilangan air; (6) peneraan meter air; (7) kecepatan penyambungan baru; (8) kemampuan penanganan pengaduan rata-rata per bulan; (9) kemudahan pelayanan; (10) rasio karyawan per 1000 pelanggan.

2. Persatuan Perusahaan Air Minum Seluruh Indonesia (PERPAMSI) tahun 2009, struktur masalah kinerja teknis PDAM yang menjadi acuan BPPSPAM dalam mengevaluasi PDAM seluruh Indonesia adalah (1) Sumber air baku; (2) Debit sumber tidak mencukupi; (3) Kebocoran fisik jaringan perpipaan; (4) Pencurian/illegal connection; (5) Kualitas air baku buruk; (6) Infrastruktur minim.

Dari 2 (dua) sumber tersebut, penulis merumuskan kembali aspek teknis yang akan menjadi faktorfaktor kepuasan pelanggan dalam penelitian ini, antara lain:

1. Kualitas air distribusi

Kualitas air distribusi dipilih karena faktor ini masuk kedalam dua acuan tersebut diatas dan juga keluhan pelanggan untuk kualitas air distribusi pada PDAM kota Denpasar sebesar 1,48 \% (sumber: rekapitulasi pengaduan external PDAM kota Denpasar tahun 2013)

2. Kontinuitas air
Pengambilan faktor kontinuitas air ini dikarenakan keluhan pelanggan PDAM kota Denpasar untuk kinerja kontinuitas air menduduki peringkat kedua, yakni sebesar 33,35\% (sumber: rekapitulasi pengaduan external PDAM kota Denpasar tahun 2013). Serta menurut penelitian Yuliarni dan Riyasa (2007) faktor ini termasuk dalam kepuasan rendah menurut pelanggan PDAM kota Denpasar.

3. Kecepatan pemasangan intalasi sambungan baru Faktor kecepatan pemasangan intalasi sambungan baru dimasukkan kedalam aspek teknis dikarenakan setiap pelanggan pasti telah melalui proses ini. Sehingga diperlukan pengukuran oleh pelanggan untuk meningkatkan kinerja kedepannya.

4. Meter air

Menurut hasil penelitian Yuliarni dan Riyasa (2007) meter air berada pada kepuasan pelanggan sedang dan pada rekapitulasi pengaduan external PDAM kota Denpasar tahun 2013 sebanyak $3,06 \%$. Sehingga faktor ini layak untuk dimasukkan kedalam aspek teknis.

5. Pengaduan mengenai perpipaan

Keluhan pelanggan terbesar PDAM kota Denpasar tahun 2013 adalah mengenai perpipaan yakni sebesar $45,49 \%$. Sehingga sangat perlu dilakukan pengukuran untuk faktor pengaduan mengenai perpipaan ini.

\section{Indikator penelitian}

Indikator-indikator dalam penelitian ini didapatkan dari penjabaran dari faktor-faktor yang mempengaruhi kepuasan pelanggan. Fungsi dari indikator ini adalah merincikan faktor yang tergolong askpek teknis. Adapun yang menjadi indikator dalam penelitian terlihat pada Tabel 1.

Tabel 1Indikator Penelitian

\begin{tabular}{|c|c|c|}
\hline NO & $\begin{array}{c}\text { Faktor-faktor } \\
\text { Aspek teknis }\end{array}$ & Indikator \\
\hline 1 & $\begin{array}{l}\text { Kualitas air } \\
\text { distribusi }\end{array}$ & $\begin{array}{l}\text { a) Kejernihan air } \\
\text { b) Rasa air } \\
\text { c) Bau air } \\
\text { d) Kandungan zat kimia }\end{array}$ \\
\hline 2 & Kontinuitas air & $\begin{array}{l}\text { a) Ketersediaan air } \\
\text { pada jam aktifitas } \\
\text { kehidupan } \\
\text { b) Kelancaran air }\end{array}$ \\
\hline 3 & $\begin{array}{l}\text { Kecepatan } \\
\text { pemasangan } \\
\text { intalasi sambungan } \\
\text { baru }\end{array}$ & $\begin{array}{l}\text { a) Kesigapan operator } \\
\text { b) Keterampilan } \\
\text { operator } \\
\text { c) Keahlian operator }\end{array}$ \\
\hline 4 & Meter air & $\begin{array}{l}\text { a) Pembacaan meter air } \\
\text { b) Peneraan dan } \\
\text { penggantian meter } \\
\text { air } \\
\text { c) Perbaikan kerusakan } \\
\text { meter air }\end{array}$ \\
\hline 5 & $\begin{array}{l}\text { Pengaduan } \\
\text { mengenai } \\
\text { perpipaan }\end{array}$ & $\begin{array}{l}\text { a) Kesigapan } \\
\text { /kecepatan } \\
\text { penanganan } \\
\text { b) Keterampilan } \\
\text { operator } \\
\text { c) Keahlian operator }\end{array}$ \\
\hline
\end{tabular}




\section{Teknis penarikan ukuran sampel}

Penarikan ukuran sampel menggunakan rumus Slovin. Data jumlah pelanggan rumah tanggan PDAM kota Denpasar per Desember 2013 adalah sebanyak 62.693 pelanggan. Menggunakan persen toleransi sebanyak 5 persen maka didapat jumlah sampel/responden sebanyak 398 orang. Jumlah responden ini dibagi berdasarkan komposisi jumlah pelanggan per kecamatan dengan teknik pemilihan sampel secara random

\section{Analisis Kepentingan (Importance) dan Kinerja} (Performance)

Analisis Importance dan Performance adalah analisis yang menunjukkan variabel-variabel yang dianggap penting oleh pelanggan, namun kinerjanya kurang. Untuk tingkat kepentingan digunakan skala likert.

Total penilaian tingkat kepentingan masing-masing variabel diperoleh dengan cara menjumlahkan hasil perkalian skor masing-masing skala dengan jumlah responden yang memilih skala tersebut. Untuk menginterpretasikan bagaimana suatu variabel dinilai oleh seluruh responden menurut tingkat kepentingan dan tingkat kinerjanya, dibutuhkan rentang skala. Adapun range pembagian kelas berdasarkan tingkat kepentingan adalah:
a. 398 - 716,4 tidak penting
b. $716,5-1.034,7$ kurang penting
c. $1.034,8-1.353,2$ cukup penting
d. $1.353,3-1.671,6$ penting
e. 1.671,7 - 1.990 Sangat penting

Sedangkan pembagian kelas berdasarkan tingkat kinerja adalah:
a. $398-716,4$ tidak baik
b. $716,5-1.034,7$ kurang baik
c. $1.034,8-1.353,2$ cukup baik
d. $1.353,3-1.671,6$ baik
e. 1.671,7 - 1.990 Sangat baik

Setelah didapat hasil tingkat kepentingan dan tingkat kinerja setiap variabel yang diukur dari seluruh sampel, selanjutnya adalah memplotkan hasil perhitungan kedalam matriks importance \& performance, yaitu dengan menghubungkan nilai performance pada sumbu $\mathrm{X}$ dan importance pada sumbu Y. adapun rumus yang digunakan adalah sebagi berikut (Martilla dan James, 1977 dalam Widyaningrum,2004):

$\begin{array}{lll}\overline{X_{l}}=\sum \frac{X_{i}}{\mathrm{n}} & \text { dan } & \overline{Y_{L}}=\sum \frac{Y_{i}}{\mathrm{n}} \\ \overline{\overline{X l}}=\sum \frac{\overline{X_{l}}}{K} & \text { dan } & \overline{Y_{l}}=\sum \frac{\overline{Y_{l}}}{K}\end{array}$

Dengan:

$\overline{X l}$ : skor rata-rata setiap variabel i pada tingkat kinerja

$\overline{Y l}:$ skor rata-rata setiap variabel i pada tingkat kepentingan

$X i$ : total skor setiap variabel i pada tingkat kinerja dari seluruh responden

$Y i$ : total skor setiap variabel i pada tingkat kinerja dari seluruh responden
$\overline{\overline{X l}}$ : rata-rata dari total rata-rata bobot tingkat kinerja

$\bar{Y}_{l}$ : rata-rata dari total rata-rata bobot tingkat kepentingan

$\mathrm{n} \quad$ : total responden

$\mathrm{K}$ : jumlah variabel yang ditetapkan

Adapun matriks dari tingkat kepentingan dan kinerja menurut Rangkuti, 2003 adalah seperti pada Gambar 1

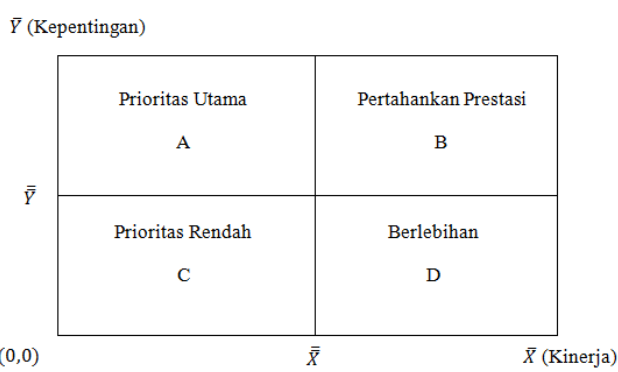

Gambar 1 Matriks Importance \& Performance

Keterangan:

A. Faktor-faktor yang dianggap penting oleh pelanggan tetapi pada kenyataannya faktorfaktor ini belum sesuai seperti yang diharapkan.

B. Faktor-faktor yang dianggap penting oleh pelanggan dan faktor-faktor yang dianggap pelanggan sudah sesuai dengan apa yang dirasakannya sehingga tingkat kepuasannya relative lebih tinggi.

C. Faktor-faktor yang dianggap kurang penting oleh pelanggan dan pada kenyataannya kinerjanya tidak terlalu istimewa.

D. Faktor-faktor yang dianggap kurang penting oleh pelanggan dan dirasakan terlalu berlebihan.

\section{Analisis Gap/Kesenjangan} Gap/Kesenjangan

ketidaksesuaian antara pelayanan yang dipersepsikan dan pelayanan yang diharapkan. Kesenjangan dapat terjadi apabila pelanggan mempersepsikan tingkat pelayanan lebih tinggi dari pada keinginan/harapan terhadap produk (desired service) atau lebih rendah daripada ketercukupan terhadap service (adequate service) kepentingan pelanggan.

Jika nilai kinerja suatu variabel lebih tinggi daripada tingkat harapan maka pelanggan akan merasa puas. Akan tetapi sebaliknya, jika kinerja lebih rendah dari tingkat harapan, maka pelanggan tidak puas atau kecewa terhadap pelayanan.

Tingkat kesesuaian didapat dari pembagian nilai tingkat kinerja (Xi) dengan nilai tingkat kepentingan (Yi). Sedangkan analisis gap didapat dari pengurangan nilai tingkat kinerja $(\mathrm{Xi})$ dengan nilai tingkat kepentingan (Yi), seperti yang ditunjukan pada rumus berikut:

Analisis Gap $\quad=X i-Y i$

Tingkat Kesesuaian $\quad=X i / Y i$ 
Untuk menentukan tingkat kepuasan pelanggan akan digunakan batasan berikut (Kuncoro dalam Yuliarni, 2007):

$\mathrm{I} \geq \mathrm{X}+\mathrm{SD} \quad$ : dikategorikan kepuasan tinggi $\mathrm{X} \leq \mathrm{I}<\mathrm{X}+\mathrm{SD}$ : dikategorikan kepuasan sedang $\mathrm{X}-\mathrm{SD} \leq \mathrm{I}<\mathrm{X}$ : dikategorikan kepuasan rendah $\mathrm{I}<\mathrm{X}-\overline{\mathrm{SD}} \quad$ : dikategorikan kepuasan sangat Keterangan:

I : Nilai Indikator

X : Rata-rata Gap

SD : Standar Deviasi

\section{HASIL DAN PEMBAHASAN}

\section{Analisis Importance dan Performance}

Nilai rata-rata tingkat kepentingan $(\overline{\bar{Y}})$ dan tingkat kinerja $(\overline{\bar{X}})$ akan menjadi batasan kuadrankuadran pada matriks importance-performance untuk menempatkan masing-masing indikator aspek teknis. Nilai total rata-rata untuk tingkat kepentingan $(\overline{\bar{Y}})$ yaitu sebesar 4,20 dan nilai total rata-rata untuk tingkat kinerja $(\overline{\bar{X}})$ yaitu sebesar 3.19. Sebaran nilai-nilai indikator aspek teknis kepuasan pelanggan PDAM kota Denpasar pada kuadran matriks Importance-Performance terlihat pada Gambar 2.

Gambar 2 Matriks Importance-Performance dari aspek teknis penilaian pelayanan

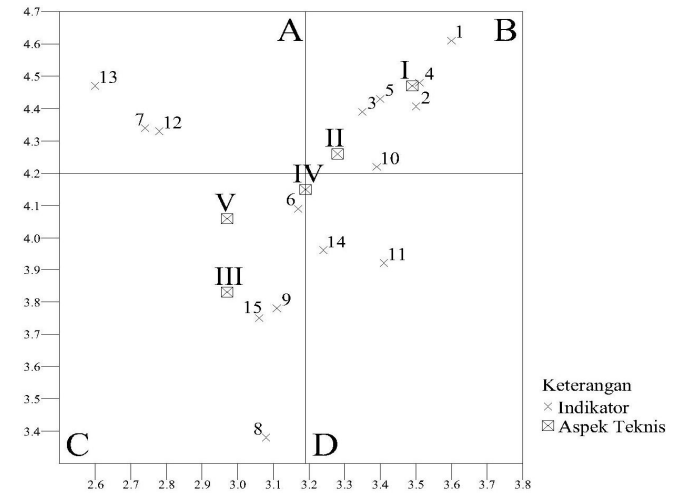

PDAM kota Denpasar

Matriks Importance-Performance terbagi menjadi empat kuadran. Masing-masing kuadran menggambarkan kondisi yang berbeda. Penjelasan masing-masing aspek teknis penilaian pelayanan PDAM kota Denpasar adalah sebagai berikut:

\section{Kuadran A (Prioritas Utama)}

Kuadran A adalah wilayah yang memuat indikator-indikator yang diaggap penting oleh pelanggan tetapi pada kenyataannya indikator ini belum sesuai dengan harapan pelanggan. Dari hasil perhitungan rata-rata aspek teknis, tidak ada aspek teknis yang termasuk dalam kuadran ini.

Namun untuk penilaian indikatorindikator pelayanan aspek teknis, ada beberapa indikator yang termasuk dalam kuadran ini, sehingga perlu diadakan peningkatan kualitas pelayanan untuk indikator ini. Adapun indikator yang termasuk dalam kuadran A adalah sebagai berikut:

a) Kesigapan operator dalam pemasangan intalasi sambungan baru (7)

b) Perbaikan kerusakan meter air (12)

c) Kesigapan/kecepatan penanganan pengaduan mengenai perpipaan (13)

\section{Kuadran B (Pertahankan Prestasi)}

Kuadaran B merupakan wilayah yang memuat indikator-indikator yang dianggap pelanggan sudah sesuai dengan yang mereka harapkan. indikator yang termasuk dalam kuadran ini harus tetap dipertahanakan karena hal ini menjadi produk/jasa unggulan.

Ada pun aspek teknis yang termasuk dalam kuadran ini adalah aspek kualitas air dan aspek kontinuitas air. Menurut penilaian pelanggan PDAM kota Denpasar, seluruh indikator dalam aspek teknis kualitas air sudah seperti yang diharapakan. Sehingga dapat disimpulkan bahwa aspek teknis kualitas air yang didistribusikan oleh PDAM kota Denpasar merupakan produk unggulan. Indikator-indikator yang termasuk dalam kuadran B adalah sebagai berikut:

a) Kejernihan air (1)

b) Rasa air (2)

c) Bau air (3)

d) Kandungan zat kimia (4)

e) Ketersediaan air pada jam aktifitas kehidupan 5)

f) Pembacaan meter air (10)

\section{Kuadran C (Prioritas Rendah)}

Kuadaran C merupakan wilayah yang memuat indikator-indikator yang dianggap pelanggan kurang penting dan pada kenyataannya kinerjanya tidak terlalu memuaskan/istimewa. Dari hasil perhitungan rata-rata aspek teknis, didapat aspek teknis yang termasuk dalam kuadran ini adalah aspek kecepatan pemasangan intalasi baru, aspek penanganan pengaduan mengenai perpipaan dan aspek meter air. Aspek meter air berada diantara kuadran $\mathrm{C}$ dan kuadran D, karena terletak pada garis pembagi tingkat kinerja.

Peningkatan indikator yang termasuk dalam kuadran ini perlu dipertimbangkan kembali karena berpengaruh pada manfaat yang dirasakan oleh pelanggan sangat kecil. Indikator-indikator yang termasuk dalam kuadran $\mathrm{C}$ adalah sebagai berikut:

a) Kelancaran air (6)

b) Keterampilan operator dalam pemasangan intalasi sambungan baru (8)

c) Keahlian operator dalam pemasangan intalasi sambungan baru (9)

d) Keahlian operator dalam menangani pengaduan mengenai perpipaan (15)

\section{Kuadran D (Berlebihan)}

Kuadaran D merupakan wilayah yang memuat indikator-indikator yang dianggap pelanggan kurang penting dan dirasakan berlebihan. Pengurangan untuk kinerja indikator yang termasuk dalam kuadran ini dapat dilakukan karena dapat 
menghemat biaya. Indikator-indikator yang termasuk dalam kuadran $\mathrm{D}$ adalah sebagai berikut:

a) Peneraan dan penggantian meter air (11)

b) Keterampilan operator dalam menangani pengaduan mengenai perpipaan (14)

Peringkat Tingkat Kepentingan dan Tingkat Kinerja

Peringkat tingkat kepentingan dan tingkat kinerja ini berguna untuk mengetahui urutan penilaian yang diberikan pelanggan terhadap indikator-indikator yang ada. Adapun peringkat masing-masing indikator pada tingkat kepentingan dan tingkat kinerja dapat dilihat padda Tabel 2 dan tabel 3.

Tabel 2 Peringkat Tingkat Kepentingan Terhadap Indikator-indikator Aspek Teknis PDAM Kota Denpasar

\begin{tabular}{|c|c|c|c|}
\hline No & Indikator & Keterangan & $\begin{array}{l}\text { Nilai } \\
\text { Rata- } \\
\text { rata }\end{array}$ \\
\hline 1 & 1 & Kejernihan air & 4.61 \\
\hline 2 & 4 & Kandungan zat kimia & 4.48 \\
\hline 3 & 13 & $\begin{array}{l}\text { Kesigapan/kecepatan } \\
\text { dalam menangani } \\
\text { pengaduan perpipaan }\end{array}$ & 4.47 \\
\hline 4 & 5 & $\begin{array}{l}\text { Ketersediaan air pada } \\
\text { jam aktifitas kehidupan }\end{array}$ & 4.43 \\
\hline 5 & 2 & Rasa air & 4.41 \\
\hline 6 & 3 & Bau air & 4.39 \\
\hline 7 & 7 & $\begin{array}{lr}\begin{array}{l}\text { Kesigapan } \\
\text { dalam }\end{array} & \text { operator } \\
\text { intalasi baru } & \end{array}$ & 4.34 \\
\hline 8 & 12 & $\begin{array}{l}\text { Perbaikan kerusakan } \\
\text { meter air }\end{array}$ & 4.33 \\
\hline 9 & 10 & Pembacaan meter air & 4.22 \\
\hline 10 & 6 & Kelancaran air & 4.09 \\
\hline 11 & 14 & $\begin{array}{l}\text { Keterampilan operator } \\
\text { dalam menangani } \\
\text { pengaduan perpipaan }\end{array}$ & 3.96 \\
\hline 12 & 11 & $\begin{array}{l}\text { Peneraan dan } \\
\text { penggantian meter air }\end{array}$ & 3.92 \\
\hline 13 & 9 & $\begin{array}{l}\text { Keahlian operator dalam } \\
\text { pemasangan intalasi } \\
\text { baru }\end{array}$ & 3.78 \\
\hline 14 & 15 & $\begin{array}{l}\text { Keahlian operator dalam } \\
\text { menangani pengaduan } \\
\text { perpipaan }\end{array}$ & 3.75 \\
\hline 15 & 8 & $\begin{array}{l}\text { Keterampilan operator } \\
\text { dalam pemasangan } \\
\text { intalasi baru }\end{array}$ & 3.38 \\
\hline
\end{tabular}

Sumber: hasil perhitungan data (2014)

Pada tabel 2 di atas terlihat bahwa indikator yang kejenernihan air yang didistribusikan oleh PDAM kota Denpasar memiliki nilai rata-rata tertinggi dengan nilai rata-rata 4.61, hal ini menunjukan bahwa indikator ini sangat penting (nilai antara 4.20-5) menurut pelanggan. Indikator yang menurut pelanggan sangat penting ada 9 (Sembilan) indikator yakni kejernihan air, kandungan zat kimia, kesigapan/kecepatan dalam menanngani pengaduan perpipaan, ketersediaan air pada jam aktifitas kehidupan, rasa air, bau air, kesigapan operator dalam pemasangan intalasi baru, perbaikan kerusakan meter air, dan pembacaan meter air.

Indikator yang dinilai penting (nilai antara 3.40-4.19) oleh pelanggan PDAM kota Denpasar ada 5 (lima) yakni kelancaran air, keterampilan operator dalam menangani pengaduan perpipaan, peneraan dan penggantian meter air, keahlian operator dalam pemasangan intalasi baru dan keahlian operator dalam menangani pengaduan perpipaan. Sedangkan yang dirasakan cukup penting (nilai antara 2.60-3.39) adalah keterampilan operator dalam pemasangan intalasi baru.

Tabel 3 Peringkat Tingkat Kinerja Terhadap Indikator-indikator Aspek Teknis PDAM Kota Denpasar

\begin{tabular}{|c|c|c|c|}
\hline No & Indikator & Keterangan & $\begin{array}{l}\text { Nilai } \\
\text { Rata- } \\
\text { rata }\end{array}$ \\
\hline 1 & 1 & Kejernihan air & 3.60 \\
\hline 2 & 4 & Kandungan zat kimia & 3.51 \\
\hline 3 & 2 & Rasa air & 3.50 \\
\hline 4 & 11 & $\begin{array}{l}\text { Peneraan dan } \\
\text { penggantian meter air }\end{array}$ & 3.41 \\
\hline 5 & 5 & $\begin{array}{l}\text { Ketersediaan air pada } \\
\text { jam aktifitas kehidupan }\end{array}$ & 3.40 \\
\hline 6 & 10 & Pembacaan meter air & 3.39 \\
\hline 7 & 3 & Bau air & 3.35 \\
\hline 8 & 14 & $\begin{array}{l}\text { Keterampilan operator } \\
\text { dalam menangani } \\
\text { pengaduan perpipaan }\end{array}$ & 3.24 \\
\hline 9 & 6 & Kelancaran air & 3.17 \\
\hline 10 & 9 & $\begin{array}{l}\text { Keahlian operator dalam } \\
\text { pemasangan intalasi } \\
\text { baru }\end{array}$ & 3.11 \\
\hline 11 & 8 & $\begin{array}{l}\text { Keterampilan operator } \\
\text { dalam pemasangan } \\
\text { intalasi baru }\end{array}$ & 3.08 \\
\hline 12 & 15 & $\begin{array}{l}\text { Keahlian operator dalam } \\
\text { menangani pengaduan } \\
\text { perpipaan }\end{array}$ & 3.06 \\
\hline 13 & 12 & $\begin{array}{l}\text { Perbaikan kerusakan } \\
\text { meter air }\end{array}$ & 2.78 \\
\hline 14 & 7 & $\begin{array}{lr}\text { Kesigapan } & \text { operator } \\
\text { dalam pemasangan } \\
\text { intalasi baru }\end{array}$ & 2.74 \\
\hline 15 & 13 & $\begin{array}{l}\text { Kesigapan/kecepatan } \\
\text { dalam menangani } \\
\text { pengaduan perpipaan }\end{array}$ & 2.60 \\
\hline
\end{tabular}
Sumber: hasil perhitungan data (2014)

Pada Tabel 3 di atas terlihat bahwa indikator yang kejenernihan air yang didistribusikan oleh PDAM kota Denpasar memiliki nilai rata-rata tertinggi dengan nilai rata-rata 4.60 , hal ini menunjukan bahwa indikator ini dinilai baik oleh pelanggan. Indikator yang dinilai baik (nilai antara 3.40-4.19) oleh pelanggan berjumlah 5 (lima) yakni kejernihan air, kandungan zat kimia, rasa air, peneraan dan penggantian meter air dan ketersediaan air pada jam aktifitas kehidupan.

Inikator yang dinilai pelanggan PDAM kota Denpasar cukup baik (nilai antara 2.60-3.39) 
Tabel 4 Hasil Analisis Gap

\begin{tabular}{|c|c|c|c|c|}
\hline \multicolumn{2}{|r|}{ Keterangan indikator } & $\begin{array}{l}\text { GAP } \\
\text { Indikat } \\
\text { or }\end{array}$ & $\begin{array}{l}\text { Rata- } \\
\text { rata } \\
\text { GAP }\end{array}$ & Ket. \\
\hline \multicolumn{3}{|c|}{ Kualitas air distribusi } & \multirow{5}{*}{-0.982} & \multirow{5}{*}{$\begin{array}{l}\text { Sedan } \\
\mathrm{g}\end{array}$} \\
\hline 1 & Kejernihan air & -1.01 & & \\
\hline 2 & Rasa air & -0.91 & & \\
\hline 3 & Bau air & -1.05 & & \\
\hline 4 & $\begin{array}{l}\text { Kandungan zat } \\
\text { kimia }\end{array}$ & -0.96 & & \\
\hline \multicolumn{2}{|c|}{ Kontinuitas air } & & \multirow{3}{*}{-0.975} & \multirow{3}{*}{$\begin{array}{c}\text { Sedan } \\
\quad \mathrm{g}\end{array}$} \\
\hline 5 & $\begin{array}{l}\text { Ketersediaan air } \\
\text { pada jam aktifitas } \\
\text { kehidupan }\end{array}$ & -1.03 & & \\
\hline 6 & Kelancaran air & -0.92 & & \\
\hline \multicolumn{2}{|c|}{$\begin{array}{lr}\text { Kecepatan } & \text { pemasangan } \\
\text { intalasi } & \text { sambungan } \\
\text { baru } & \end{array}$} & & \multirow{4}{*}{-1.003} & \multirow{4}{*}{$\begin{array}{l}\text { Sedan } \\
\mathrm{g}\end{array}$} \\
\hline 7 & $\begin{array}{l}\text { Kesigapan operator } \\
\text { dalam pemasangan } \\
\text { intalasi baru }\end{array}$ & -1.59 & & \\
\hline 8 & $\begin{array}{l}\text { Keterampilan } \\
\text { operator dalam } \\
\text { pemasangan intalasi } \\
\text { baru }\end{array}$ & -0.75 & & \\
\hline 9 & $\begin{array}{l}\text { Keahlian operator } \\
\text { dalam pemasangan } \\
\text { intalasi baru }\end{array}$ & -0.67 & & \\
\hline \multicolumn{2}{|c|}{ Meter air } & & \multirow{4}{*}{-0.973} & \multirow{4}{*}{$\begin{array}{c}\text { Sedan } \\
\mathbf{g}\end{array}$} \\
\hline $\begin{array}{l}1 \\
0\end{array}$ & $\begin{array}{ll}\text { Pembacaan meter } \\
\text { air }\end{array}$ & -0.84 & & \\
\hline $\begin{array}{l}1 \\
1\end{array}$ & $\begin{array}{lr}\begin{array}{l}\text { Peneraan } \\
\text { penggantian }\end{array} & \text { meter } \\
\text { air } & \\
\end{array}$ & -0.52 & & \\
\hline $\begin{array}{l}1 \\
2\end{array}$ & $\begin{array}{l}\text { Perbaikan } \\
\text { kerusakan meter air }\end{array}$ & -1.56 & & \\
\hline \multicolumn{2}{|c|}{$\begin{array}{l}\text { Pengaduan mengenai } \\
\text { perpipaan }\end{array}$} & & \multirow{4}{*}{-1.09} & \multirow{5}{*}{$\underset{\mathbf{h}}{\text { Renda }}$} \\
\hline $\begin{array}{l}1 \\
3\end{array}$ & $\begin{array}{l}\text { Kesigapan/kecepata } \\
\mathrm{n} \text { dalam menangani } \\
\text { pengaduan } \\
\text { perpipaan }\end{array}$ & -1.87 & & \\
\hline $\begin{array}{l}1 \\
4\end{array}$ & $\begin{array}{l}\text { Keterampilan } \\
\text { operator dalam } \\
\text { menangani } \\
\text { pengaduan } \\
\text { perpipaan }\end{array}$ & -0.71 & & \\
\hline $\begin{array}{l}1 \\
5\end{array}$ & $\begin{array}{l}\text { Keahlian operator } \\
\text { dalam menangani } \\
\text { pengaduan } \\
\text { perpipaan }\end{array}$ & -0.69 & & \\
\hline & Rata-rata & -1.01 & & \\
\hline
\end{tabular}

Sumber: hasil perhitungan data (2014)

sebanyak 10 (sepuluh) indikator yakni pembacaan meter air, bau air, keterampilan operator dalam menangani pengaduaan perpipaan, kelancaran air, keahlian operator dalam pemasangan intalasi baru, keterampilan operator dalam pemasangan intalasi baru, keahlian operator dalam menangani pengaduan perpipaan, perbaikan kerusakan meter air, kesigapan operator dalam pemasangan intalasi baru dan kesigapan/kecepatan dalam menangani pengaduan perpipaan.

\section{Analisis Gap}

Untuk mengetahui kepuasan pelanggan terhadap inikator-indikator aspek teknis pelayanan dapat dilihat dari kesenjangan/gap antara kepentingan dan kinerja. Apabila tingkat kinerja suatu indikator lebih tinggi dari tingkat kepentingan maka pelanggan akan merasa puas. Namun jika tingkat kinerja lebih kecil dari tingkat kepentinganan maka pelanggan kurang puas Menurut Irawan, dalam Widyaningrum (2004), kemungkinan terjadinya gap positif sangatlah kecil. Sebagian gap yang dihasilkan adalah negatif (-). Penilaian pelanggan yang baik adalah jika memiliki gap lebih kecil dari -1 (minus satu).

Pada Tabel 4 terlihat nilai tingkat kesesuaian dan rata-rata gap tiap aspek teknis. Nilai tingkat kesesuaian didapatkan dari pembagian nilai tingkat kinerja dengan nilai tingkat kepentingan. Sedangkan nilai gap didapatkan dari pengurangan nilai tingkat kinerja dengan nilai tingkat kepentingan. Disimpulkan bahwa aspek pengaduan mengenai perpipaan berada pada tingkat kepuasan rendah. Tingkat kepuasan untuk aspek kualitas air, kontinuitas air, kecepatan pemasangan intalasi sambungan baru dan meter air berada pada tingkat kepuasan sedang.

Indikator yang memiliki nilai kesenjangan terbesar adalah kesigapan/kecepatan dalam menangani pengaduan perpipaan (13). Indikator kesigapan/kecepatan dalam menangani pengaduan perpipaan ini memiliki kepentingan yang tinggi, artinya pelanggan menggap bahwa kesigapan/kecepatan dalam menangani pengaduan perpipaan adalah bagian terpenting dalam aspek teknis pelayanan PDAM kota Denpasar. Namun pada kenyataannya kinerja kesigapan/kecepatan dalam menangani pengaduan perpipaan masih dirasakan kurang oleh pelanggan. Menurut data pengaduan external PDAM kota Denpasar terlihat bahwa pengaduan mengenai perpipaan merupakan keluhan yang paling banyak terjadi sepanjang tahun 2013 yakni sebesar $45,49 \%$ dari 6.738 keluhan yang masuk. Untuk meningkatkan kepuasan pelanggan PDAM kota Denpasar maka diharapaka indikator kesigapan/kecepatan dalam menangani pengaduan perpipaan harus ditingkatkan.

Adapun indikator yang memiliki kesenjangan terkecil adalah peneraan dan penggantian meter air. Dalam hal ini pelanggan menilai bahwa peneraan dan penggantian meter air tidak terlalu penting dibandingkan dengan indikator lain dalam aspek teknis. Sehingga untuk peningkatan kinerja indikator ini dapat ditunda/tidak dilakukan, dikarenakan untuk penghematan biaya operasional. 
Nilai gap beberapa indikator lebih besar dari nilai gap rata-rata $(-1.01)$. hal ini berarti indikator tersebut harus diperbaiki/ditingkatkan kinerjanya untuk mengingkatkan kepuasan pelanggan. Indikator tersebut adalah kejernihan air (-1.01), bau air (-1.05), ketersediaan air pada jam aktifitas kehidupan (-1.03), kesigapan operator dalam pemasangan intalasi baru (-1.59), perbaikan kerusakan meter air (-1.56), kesigapan/kecepatan dalam menangani pengaduan perpipaan $(-1.87)$.

\section{SIMPULAN DAN SARAN \\ Simpulan}

Berdasarkan pembahasan dari penelitian ini didapatkan kesimpulan sebagai berikut:

1. Tingkat kepuasan pelanggan PDAM kota Denpasar untuk aspek pengaduan mengenai perpipaan $(-1,09)$ berada pada tingkat kepuasan rendah $(-1,059 \leq \mathrm{I}<-1,01)$ sedangkan kepuasan untuk aspek kualitas air $(-0,982)$, kontinuitas air $(-0,975)$, kecepatan pemasangan instalasi sambungan baru $\quad(-1,003)$ dan meter air ($0,973)$ berada pada tingkat kepuasan sedang ($1,01 \leq \mathrm{I}<-0,961)$.

2. Indikator-indikator yang berpengaruh terhadap kepuasan pelanggan adalah indikator yang termasuk dalam daerah A (prioritas utama) dan daerah B (pertahankan prestasi) pada matriks Importance-Perfoemance dan memiliki nilai kepentingan lebih besar dari 4,17. Indikatorindikator tersebut adalah kejernihan air $(4,61)$, bau air $(4,39)$, rasa air $(4,41)$, kandungan zat kimia $(4,48)$, ketersediaan air pada jam aktifitas kehidupan $(4,43)$, kesigapan operator dalam pemasangan instalasi sambungan baru $(4,34)$, pembacaan meter air $(4,22)$, perbaikan kerusakan meter air $(4,33)$ dan kesigapan/kecepatan penanganan pengaduan mengenai perpipaan $(4,47)$.

\section{DAFTAR PUSTAKA}

Agustina, D.T, 2007, Analisa Kinerja Sistem Distribusi Air Bersih PDAM Kec. Banyumanik di Perumahan Banyumanik (Studi Kasus Perumnas Banyumanik Kel. Srondol Wetan), Tesis, Semarang: Universitas Diponogoro.

Anonim. 1999. Keputusan Menteri Dalam Negeri Nomor 47 tahun 1999. "Pedoman Penilaian Kinerja Perusahaan Daerah Air Minum”. Jakarta: Departemen Dalam Negeri RI.

Anonim. 2010. Kerjasama Pemerintah dan swasta (KPS). "Panduang Bagi Investor dalam Investasi di Bidang Infrastruktur”. Jakarta: Kementrian Koordinator Bidang Perekonomian RI.

Anonim. 2010. Peta Masalah PDAM. Ringkasan Eksekutif. Jakarta: Persatuan Perusahaan Air Minum seluruh Indonesia.

Putra, C.G.D.2011. “Analisis Kepuasan Pelanggan Pada Perusahaan daerah air Minum (PDAM) di Kabupaten Jembrana”. (Tesis). Denpasar: Universitas Udayana.
3. Indikator yang harus diperbaiki berdasarkan analisis Importance-Performance adalah indikator yang termasuk dalam kuadaran A (prioritas utama). Sedangkan berdasarkan perhitungan analisi gap adalah nilai gap yang lebih besar negatifnya dari nilai gap rata-rata (1.01). Indikator-indikator tersebut adalah kejernihan air $(-1,01)$, bau air $(-1,05)$, ketersediaan air pada jam aktifitas kehidupan ($1,03)$, kesigapan operator dalam pemasangan instalasi sambungan baru $\quad(-1,59)$, perbaikan kerusakan meter air $(-1,56)$ dan kesigapan/kecepatan penanganan pengaduan mengenai perpipaan $(-1,87)$.

\section{Saran}

Untuk meningkatkan kepuasan pelanggan PDAM kota Denpasar, disarankan beberapa hal sebagai berikut:

1. PDAM kota Denpasar harus meningkatkan pelayanan dalam penanganan pengaduan mengenai perpipaan yang berada pada tingkat kepuasan rendah dengan cara menambah jumlah operator dan meningkatkan sumber daya manusia (kesigapan, keahlian dan keterampilan operator).

2. Hal lain yang harus diperhatikan adalah dari aspek kualitas air distribusi (kejernihan air dan bau air) sedangkan dari aspek kontinuitas harus diperhatikan ketersediaan air pada jam aktifitas kehidupan antara pukul 6 pagi hingga 6 sore serta kesigapan operator dalam pemasangan instalasi sambungan baru dan perbaikan kerusakan meter air.

3. Perlu diadakan penelitian secara berkala untuk mengetahui kepuasan pelanggan terhadap kualitas pelayanan PDAM kota Denpasar terutama pada aspek teknis. Hal ini dapat menjadi acuan perusahaan dalam memberikan pelayanan terbaik kepada pelanggan.

Narbuko, Cholid dan Achmadi A. 2010. Metodologi Penelitian. Cet. 11. Jakarta: Bumi Aksara.

Prasetyani, N. 2009. Analisis kinerja Pelayanan Publik Perusahaan Daerah Air Minum (PDAM) Kabupaten Demak. (Tesis). Semarang: Universitas Dipenogoro.

Rochmah, S. Analisis Kepuasan Pelanggan Terhadap Kualitas Pelayanan Perusahaan Daerah Air Minum (Studi pada PDAM Kota Malang). (Skripsi). Malang: Universitas Brawijaya.

Siregar, S. 2013, Metode Pelenelitian Kuantitatif :dilengkapi dengan perbandingan perhitungan manual dan SPSS, Jakarta, Penerbit: Kencana Prenada Media Group.

Website Perusahaan Daerah Air Minum Kota Denpasar. Available from: URL: http://pdam.denpasarkota.go.id/.

Widyaningrum, R. 2004. Analisis Kualitas Pelayanan Terhadap Kepuasan Pelanggan (studi Kasus di PDAM Tirta Pakuan Kota Bogor). Bogor: Institut Pertanian Bogor. 